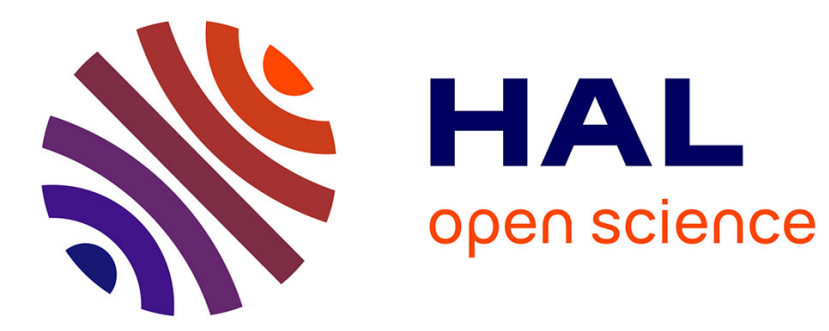

\title{
Early summer soil moisture contribution to Western European summer warming
}

\author{
A. Stegehuis, M. Vogel, R Vautard, P Ciais, A. Teuling, S. Seneviratne
}

\section{To cite this version:}

A. Stegehuis, M. Vogel, R Vautard, P Ciais, A. Teuling, et al.. Early summer soil moisture contribution to Western European summer warming. Journal of Geophysical Research: Atmospheres, 2021, 126 (17), pp.e2021JD034646. 10.1029/2021JD034646 . hal-03317913

\section{HAL Id: hal-03317913 \\ https://hal.science/hal-03317913}

Submitted on 16 Sep 2021

HAL is a multi-disciplinary open access archive for the deposit and dissemination of scientific research documents, whether they are published or not. The documents may come from teaching and research institutions in France or abroad, or from public or private research centers.
L'archive ouverte pluridisciplinaire HAL, est destinée au dépôt et à la diffusion de documents scientifiques de niveau recherche, publiés ou non, émanant des établissements d'enseignement et de recherche français ou étrangers, des laboratoires publics ou privés. 


\section{JGR Atmospheres}

\author{
RESEARCH ARTICLE \\ 10.1029/2021JD034646 \\ Key Points: \\ - Increasing early summer soil \\ moisture deficit explains almost all \\ of the rapid recent warming summer \\ trend in Western Europe \\ - Large-scale drivers explain up to \\ $1^{\circ} \mathrm{C}$.decade -1 of the warming \\ summer trend in Eastern Europe \\ - Our results emphasize a crucial \\ role of pre-summer water cycling \\ in current and future evolutions of \\ Western European summer climate
}

Supporting Information:

Supporting Information may be found in the online version of this article.

Correspondence to:

A. I. Stegehuis,

stegehuis@fld.czu.cz

Citation:

Stegehuis, A. I., Vogel, M. M.,

Vautard, R., Ciais, P., Teuling, A. J., \& Seneviratne, S. I. (2021). Early summer soil moisture contribution to Western European summer warming. Journal of Geophysical Research: Atmospheres, 126, e2021JD034646. https://doi. org/10.1029/2021JD034646

Received 29 JAN 2021

Accepted 24 JUL 2021

Author Contributions:

Conceptualization: A. I. Stegehuis, R. Vautard, P. Ciais, A. J. Teuling, S. I. Seneviratne

Formal analysis: A. I. Stegehuis, M M. Vogel

Methodology: A. I. Stegehuis, M. M. Vogel, R. Vautard, P. Ciais, A. J. Teuling, S. I. Seneviratne

Supervision: R. Vautard

Visualization: A. I. Stegehuis

Writing - original draft: A. I.

Stegehuis, R. Vautard

Writing - review \& editing: $M$. M. Vogel, P. Ciais, A. J. Teuling, S. I. Seneviratne

(c) 2021. American Geophysical Union. All Rights Reserved.

\section{Early Summer Soil Moisture Contribution to Western European Summer Warming}

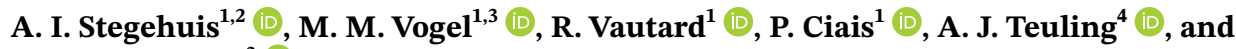 \\ S. I. Seneviratne ${ }^{3}$ (D) \\ ${ }^{1}$ LSCE/IPSL Laboratoire CEA/CNRS/UVSQ, Université de Paris Saclay, Gif-sur-Yvette, France, ${ }^{2}$ Department of Forest \\ Ecology, Faculty of Forestry and Wood Sciences, Czech University of Life Sciences Prague, Prague, Czech Republic, \\ ${ }^{3}$ Institute for Atmospheric and Climate Science, Zürich, Switzerland, ${ }^{4}$ Hydrology and Quantitative Water Management \\ Group, Wageningen University, Wageningen, The Netherlands
}

Abstract Warm European summer temperatures are often preceded by low soil moisture conditions, but also depend on the atmospheric circulations and associated rainfall that may trigger drought to persist and land-atmosphere feedbacks to take place. The quantitative role of early summer soil moisture (ESSM) trends, versus that of trends in atmospheric circulations and other large-scale drivers (LS), in explaining the long-term trends in summer warming have not been investigated so far. Using regional climate simulations with forced large-scale circulation and different possible initial soil moisture, we show that the increasing ESSM deficit explains almost all of the warming summer trend (1980-2011) in Western Europe $\left(\sim 0.1-0.2^{\circ} \mathrm{C}\right.$ decade ${ }^{-1}, \mathrm{p}$-value $\left.<0.05\right)$. It also contributed a similar amount to summer warming trend in Eastern Europe, although here LS explains a much larger part of the overall warming. Our results emphasize the crucial role of the pre-summer water cycle in current and future regional evolutions of Western European summer climate.

Plain Language Summary During the last decades the summers in Europe have become warmer. It is important to understand this change in order to be able to mitigate future warmer summers. The warming is partly due to local and regional drying of the soil, but also to the climate and winds at a larger scale than Europe. This has already been found in other work, but the two contributions were never quantified before in the long-term trend of summer warming. In this research we investigate how many degrees the soil moisture and the larger scale climate contributed to the European summer warming. We found that a changing soil moisture at the beginning of the summer caused a temperature increase of $\sim 0.1-0.2^{\circ} \mathrm{C}_{\text {decade }}{ }^{-1}$ in Central and Western Europe. This was the same in Eastern Europe but there we found that the larger scale climate was more important and caused an increase of up to $\sim 1^{\circ} \mathrm{C} \cdot \mathrm{decade}^{-1}$. This means that adapting land management policies to hold more winter and spring water can especially have a positive effect on the climate in Central and Western Europe and may be able to reduce extreme warm summers in the future.

\section{Introduction}

European temperatures, especially maximum temperatures, have increased over the last decades (Van Oldenborgh et al., 2009) and are expected to further increase in the future (Schaer et al., 2004). This is paired with a higher occurrence of mega-heatwaves and exceptional warm summers (Barriopedro et al., 2011; Samaniego et al., 2018; Schaer et al., 2004; Teuling, 2018). Such extreme climatic events can cause great damage and loss to society and ecosystems, as witnessed for example, in 2003 in Europe, 2010 in Russia and 2012 in the US (e.g., Ciais et al., 2005; Fouillet et al., 2006; Zampieri et al., 2016). The detailed mechanisms and drivers of changes in future heat events need to be better understood for improved projections and adaptation (Miralles et al., 2018).

Heatwaves, and warm summers in general, are associated with the occurrence of specific atmospheric circulation patterns along the summer, especially atmospheric blocking and south-westerly flows (Cassou et al., 2005), and low early summer soil moisture conditions. Heatwaves were shown to be strongly fostered by dry soils (Rasmijn et al., 2018; Seneviratne et al., 2010; Teuling, 2018; Vautard et al., 2007) which themselves depend on the previous sequence of rainfalls and synoptic weather patterns preceding the event 
that altogether set the levels of soil moisture in early summer. We assume here that the heat anomaly of a summer season depends on (a) the initial early summer soil moisture (ESSM) and (b) other drivers among which the sequence of large-scale circulation patterns along the summer (LS). Other large-scale drivers may include radiative forcing and sea surface temperatures (SST) but these are not analyzed separately here.

Low early summer soil moisture (ESSM) makes temperature more sensitive to the occurrence of anticyclonic weather regimes (Quesada et al., 2012). The establishment of dry summer conditions involves land-atmosphere feedbacks exacerbating the amplification of heat in such cases (Miralles et al., 2018; Rasmijn et al., 2018; Seneviratne et al., 2010). Dry soils favor sensible heat flux over latent heat flux causing an increase in temperature that in turn depletes soil moisture further generating a positive feedback loop. This effect is likely strongest in the transition zone between water and energy-limited evaporation regimes. Here, soil moisture makes excursions below the critical soil moisture in dry years, leading to high seasonal variability in fluxes and a strong correlation between fluxes and temperature (Denissen et al., 2020). Yet the role of ESSM was found to be modest for seasonal predictions forecast of temperature, and very low for seasonal precipitation forecast in global models (Koster et al., 2011). In Europe, a causal link between ESSM and summer temperature anomalies has been suggested from several observational studies (Hirschi et al., 2011; Miralles et al., 2014; Mueller \& Seneviratne, 2012). However, the quantification of this causal link is challenging due to chaotic dynamical processes. This makes the assessment of the contribution of an ESSM anomaly to an observed subsequent summer temperature anomaly difficult.

Recently, several studies have investigated the separate contribution of ESSM and LS to single heatwave events (Merrifield et al., 2019; Wehrli et al., 2019). However, long-term trends in ESSMs, due to changes in climate forcing or natural decadal variability may also contribute to the summer warming trend and have not been investigated in a similar way to our knowledge. In this context, a systematic attribution of summer heatwaves to ESSM versus changes in other large-scale drivers conditioning the occurrence of hot or cold summer weather is needed. The aim of our work is to quantify the contribution of ESSM to the long-term summer temperature trend in Europe as well as the relative contribution of ESSM versus LS to the interannual variability of summer temperatures. We hypothesize that the trend in ESSM significantly contributes to warming summer temperatures. We test this by using sensitivity simulations with a regional climate model in which the dynamical fields are constrained.

\section{Methods}

\subsection{Model Description}

We used the regional climate model Weather Research and Forecast (WRF) (Skamarock et al., 2008) over the EURO-CORDEX domain (Jacob et al., 2014) with a spatial resolution of $50 \mathrm{~km}\left(0.44^{\circ}\right.$ on a rotated lon-lat grid) and boundary conditions from ERA-Interim (Dee et al., 2011). For more specific details of the model setup we refer to Stegehuis et al. (2015). The set of physics schemes that were used in this study correspond to some of those tested for heatwaves in the same study. It uses the Morisson (Morrison et al., 2009) microphysics scheme, the MY-ETA PBL-Surface layer (Nakanishi \& Niino, 2006), the RRTGM radiation (Iacono et al., 2008), the Tiedtke convection scheme (Tiedtke, 1989; Zhang et al., 2011) and the NOAH land surface (Tewari et al., 2004). Note that the land surface scheme does not take the interannual variation of vegetation parameters in account, but although this effect can be important for individual extremes, it is believed to be small in this study (Lorenz et al., 2013; Van Hateren et al., 2021). A more detailed description of the physic schemes can be found in Stegehuis et al. (2015). The physics configuration that was used in this study was selected based on its ability to correctly simulate temperature, precipitation and radiation over Europe for different climatic situations in a previous study (Stegehuis et al., 2015). In that study the simulations were also tested against and observational based data set of latent heat flux and the land surface scheme was tested for latent heat flux, sensible heat flux and evaporative fraction at a few selected FLUXNET sites. The configuration was furthermore chosen to optimize not only the summer season but also the winter season. For a multi-year simulation such as the one in the control experiment, it is indeed preferable that the model also performs well during other seasons. A bias in winter or spring might still be visible in summer, as for example, soil moisture conditions, due to a long-term memory. Snow melt is also a typical cross-season process that can influence temperature and soil moisture in the early and later summer. We verified statistics for all seasons and display temperature statistics (Text S1 and Figure S1). 


Table 1
Experimental Model Set-Up

The upper-air wind of all simulations was constrained to ERA-Interim re-analysis using grid-nudging, with a nudging coefficient of $5.10^{-5} \mathrm{~s}^{-1}$. This corresponds to a relaxation time that is, approximately equivalent to the input frequency (every $6 \mathrm{~h}$ ) (Omrani et al., 2013). Nudging was necessary in our setup of attribution experiments to avoid chaotic evolution of large-scale atmospheric circulation.

\subsection{Attribution of Temperature Anomalies}

We designed sensitivity simulations over Europe to attribute the contribution of ESSM versus LS drivers to summer temperature variability and trends. The dynamical fields as well as other drivers were constrained as boundary conditions, while ESSM is varied. We used this attribution model framework to vary systematically (a) the ESSM starting values with LS conditions being constrained, (b) the LS starting values with ESSM conditions constrained. Evaluation of the respective roles of ESSM and LS was focused on the summer warming trend and the heat waves of 2003 and 2010. Wind nudging in WRF to ERA-Interim fields allowed us to constrain the wind fields above the planetary boundary layer, so that the atmospheric circulation over Europe does not make excursions away from the observed state due to internal chaotic variability. This set-up may inhibit a potential regional atmospheric flow response to ESSM anomalies. While such a response may exist in single events (Orth et al., 2016) near the surface due to the heat flow created by ESSM deficits amplifying temperature (Haarsma et al., 2008), it was found to be small in the upper atmosphere ( $\sim 5 \mathrm{~m}$ in the $500 \mathrm{hPa}$ geopotential height, see Figure 12 in Zampieri et al., 2009). This assumption of a largely decoupled regional atmospheric flow response to ESSM anomalies seemed to be realistic as no significant correlation was found between ESSM and subsequent summer observed sea level pressure or global z500 in July and August in the control experiment (not shown).

The control WRF experiment covers the period 1980 to 2011. The simulation is continuous and was initialized in January 1980 from ERA-Interim conditions. Alternative attribution simulations consist of more than 900 (32*31) simulations starting at June 30 of each year from 1980 to 2011 (Table 1). In the first set of the simulations, initial soil conditions (moisture and temperature) of one year were replaced at the end of June (June 30, 00 UTC), with the soil moisture conditions of each of the 31 other years from the control simulation, thus a different ESSM anomaly than the control simulation for the year considered (Table 1). Thereafter each simulation was run until the end of August, keeping other conditions (LS) during the whole summer season as in the control experiment, including nudging to upper-air winds. Subtracting the subsequent average summer temperature simulated by all 32 simulations with a different ESSM initial condition than the value obtained in the control simulation provided an attribution of summer temperature anomalies that are explained by the ESSM anomaly. A symmetrical ensemble of sensitivity simulations was done by varying only the LS (everything except from the soil variables replaced in the first experiment) along the July-August period of all 32 seasons, while keeping ESSM to the control value (Table 1). This allowed attribution to LS, which include SST, large-scale circulation and boundary conditions. This experiment may include some effects of later soil moisture in addition to ESSM, since changes in prescribed LS after June 30 can still change summer temperature with rainfall and temperature affecting soil moisture after the start of simulation. 
For each year, $y$, the temperature difference between the control and the average over all 32 sensitivity simulations (including the control one) then gave the temperature response $\mathrm{R}_{\mathrm{y}, \mathrm{ESSM}}$ of the soil moisture anomaly:

$$
\mathrm{R}_{\mathrm{y}, \mathrm{ESSM}}=\mathrm{T}_{\mathrm{y}}-\overline{\mathrm{T}}_{\mathrm{y}, \mathrm{ESSM}}
$$

where $T_{y}$ is the temperature of the control run for year $y$, and $\bar{T}_{y, E S S M}$ the average temperature over the 32 ensemble simulations for that year (the average over the rows in Table 1). A similar equation could be written to estimate the response of the temperature anomaly to LS contribution:

$$
\mathrm{R}_{\mathrm{y}, \mathrm{LS}}=\mathrm{T}_{\mathrm{y}}-\overline{\mathrm{T}}_{\mathrm{y}, \mathrm{LS}}
$$

where $\mathrm{T}_{\mathrm{y}}$ is the temperature of the control year and $\overline{\mathrm{T}}_{\mathrm{y}, \mathrm{LS}}$ the average temperature of the 32 sensitivity simulations (the average over the columns in Table 1).

There is no mathematical reason for which the sum of the two contributions $\left(R_{y, E S S M}\right.$ and $\left.R_{y, L S}\right)$ would add up the temperature anomaly $\mathrm{T}_{\mathrm{y}}^{\prime}$ :

$$
\mathrm{T}_{\mathrm{y}}^{\prime}=\mathrm{T}_{\mathrm{y}}-\overline{\mathrm{T}}
$$

where the long-term climatology, the mean of the control simulations, is denoted $\overline{\mathrm{T}}$. However, we verified that the sum of the two contributions $\mathrm{T}_{\mathrm{y}}^{\prime \prime}$ :

$$
\overline{\mathrm{T}}_{\mathrm{y}}^{\prime \prime}=\mathrm{R}_{\mathrm{y}, \mathrm{ESSM}}+\mathrm{R}_{\mathrm{y}, \mathrm{LS}}
$$

lied close to the temperature anomaly, that is, $\overline{\mathrm{T}}_{\mathrm{y}}^{\prime \prime} \approx \sim \overline{\mathrm{T}}_{\mathrm{y}}^{\prime}$, which is expected if we assume the two classes of processes do not strongly interact. This was tested by calculating a temporal correlation between the temperature anomaly of the control run and $\overline{\mathrm{T}}_{\mathrm{y}}^{\prime \prime}$ (See Figure S2). Note that this method has some similarities with ANOVA.

\section{Results and Discussion}

The simulated ESSM trends in the control simulation are negative (Figure S3c). This drying trend in early summer seems consistent with observations of decreasing winter precipitation in Southern Europe (Hoerling et al., 2012). The attribution simulations (Methods) reveal that ESSM has substantially increased the trend in summer temperatures, and simultaneously, the temperatures of individual heatwaves (Figure 1). The trend increased the temperatures over Western Europe over the last 30 years at a rate of approximately $0.1^{\circ} \mathrm{C}$ per decade $-0.2^{\circ} \mathrm{C}$ per decade (Figure $1 \mathrm{~h}$ ). Thus, there is a small summer temperature warming trend induced by drier soils at the onset of summer. A result that is, consistent with Seneviratne et al. (2006), who showed an increasing importance of soil moisture toward the end of the century. A large part of France, Germany and other parts of central Europe show a summer warming trend essentially contributed by ESSM (p-value $<0.05$, MannKendall trend test) (Figure 1h). In those areas, the trend in ESSM-induced warming is almost equal to the simulated warming trend due to all factors in the control simulation, despite the fact that the model slightly underestimates the warming trend as compared to observations (Figures 1g and Figure S4). An underestimation of the warming trend was also found in another set of regional climate model simulations over Europe (Lorenz \& Jacob, 2010). Some processes, such as decreased aerosol content from emission reductions increasing shortwave radiation (Wild et al., 2005), are not present in our simulations and may partly explain this underestimation. The main result here is that the early summer drying trend (Figure 2 and Figure S3c) can account for most of the small warming trend in July and August along the past three decades in many Western European areas in the simulations. In other areas, the ESSM contribution to warming trends is significant (e.g., Ukraine, significance level of 95\%), but explains a smaller fraction of the all-factors simulated warming (Figure 2).

The contribution of LS also provides a summer warming trend that does not have the same spatial pattern than the warming trend induced by ESSM (Figures 1h and 1i). Most of the LS contribution to warming is in Eastern Europe (Figure 1i). This LS contribution contains the response to SST warming, temperature, wind and humidity set as boundary conditions of the domain, and contains non-ESSM feedbacks that are coupled with LS changes during the course of the summers (Hauser et al., 2016; Seneviratne et al., 2010; Stefanon et al., 2014; Vautard et al., 2007). We also verified that the large contribution of LS to summer warming in Russia was not solely due to the presence of the extreme 2010 summer in the record. A sensitivity test 


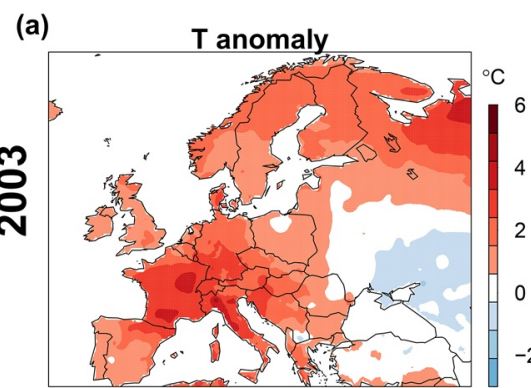

(d)

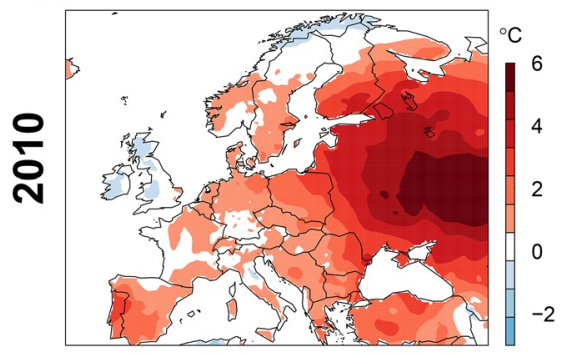

(g)

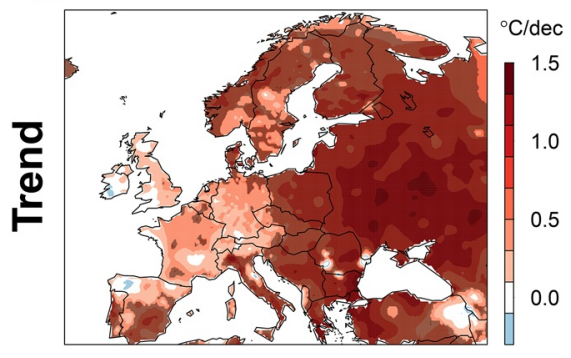

(b)

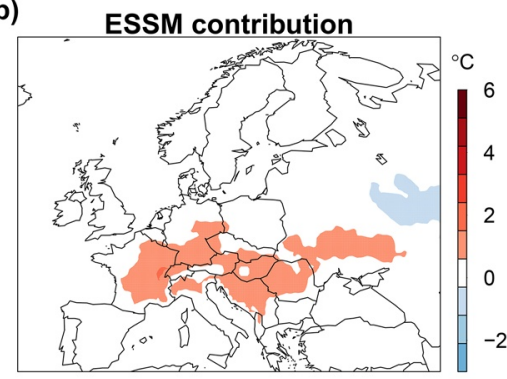

(e)

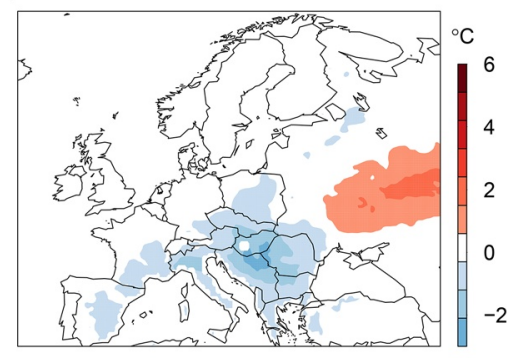

(h)

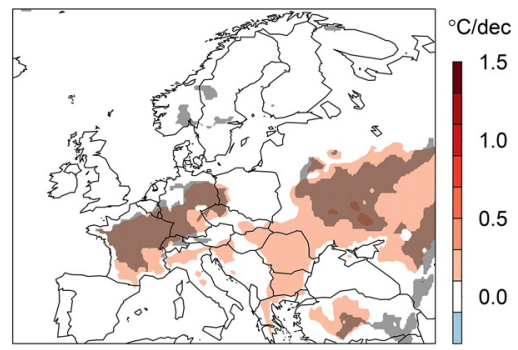

(c)

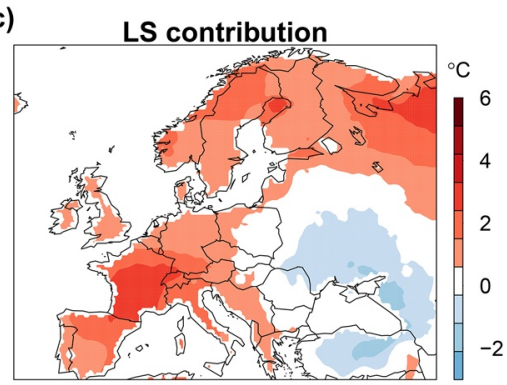

(f)

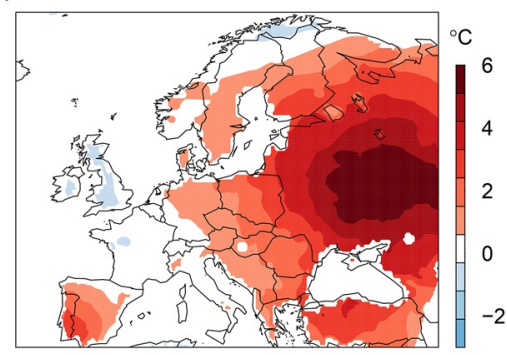

(i)

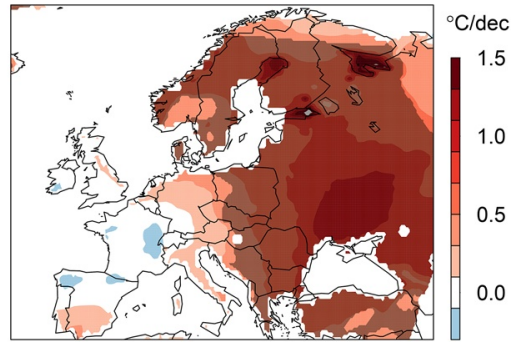

Figure 1. Contribution of early summer soil moisture (ESSM) and atmospheric large scale circulation from July to August large-scale drivers (LS) to summer temperatures of 2003 and 2010 and to the temperature trend from 1980 to 2011. The observed (from E-OBS) temperature anomalies in 2003 are in (a), 2010 (d) and the trend (g). The contribution of ESSM (b,e,h) and LS (c,f,i) to the summer (July-August) temperature anomalies of 2003 (b), (c), 2010 (e), (f) and to the trend (h), (i). Shaded areas in g-i indicate a significance level of 95\% (MannKendall trend test).

without this exceptional heatwave showed that the positive contribution of LS to the warming trend remains high (Figure S2).

The spatial patterns from the summer warming trend from LS do not overlap with those from ESSM (Figure 2). A spatially differential contribution of land atmosphere coupling versus atmospheric coupling in heatwaves was also identified in Hirsch et al. (2019) for the Australian continent. The trend in sea level pressure (SLP) shows a dipole with positive values (more anticyclonic weather) over Eastern Europe and negative ones over central and Western Europe (less anticyclonic weather, see Figure 3). This dipole of LS induced SLP trends suggests that the LS induced warming trend across Europe is attenuated by more cyclonic weather in Western Europe, leaving the ESSM contribution to dominate the summer temperature trend in this area.

We also investigate interannual variability and extremes contributed respectively by LS and ESSM. We investigate the hot summers of 2003 (in Europe except most part of Russia) and 2010 (mainly in central Russia and Northern Europe). In the positive temperature anomaly during the 2003 summer, the contribution of ESSM was found to be significant but not dominant compared to the one of LS in the temperature anomaly of July and August 2003 (Figure 1). ESSM explained approximately $1^{\circ} \mathrm{C}-1.5^{\circ} \mathrm{C}$ of the summer 2003 temperature anomaly in Western and Central Europe ( 20\%) (Figure 1a). This area corresponds with the area where SM deficits were largest ( $-10 \%$ to $-50 \%$ ) (Figure S3a). The contribution of ESSM was a bit smaller in 


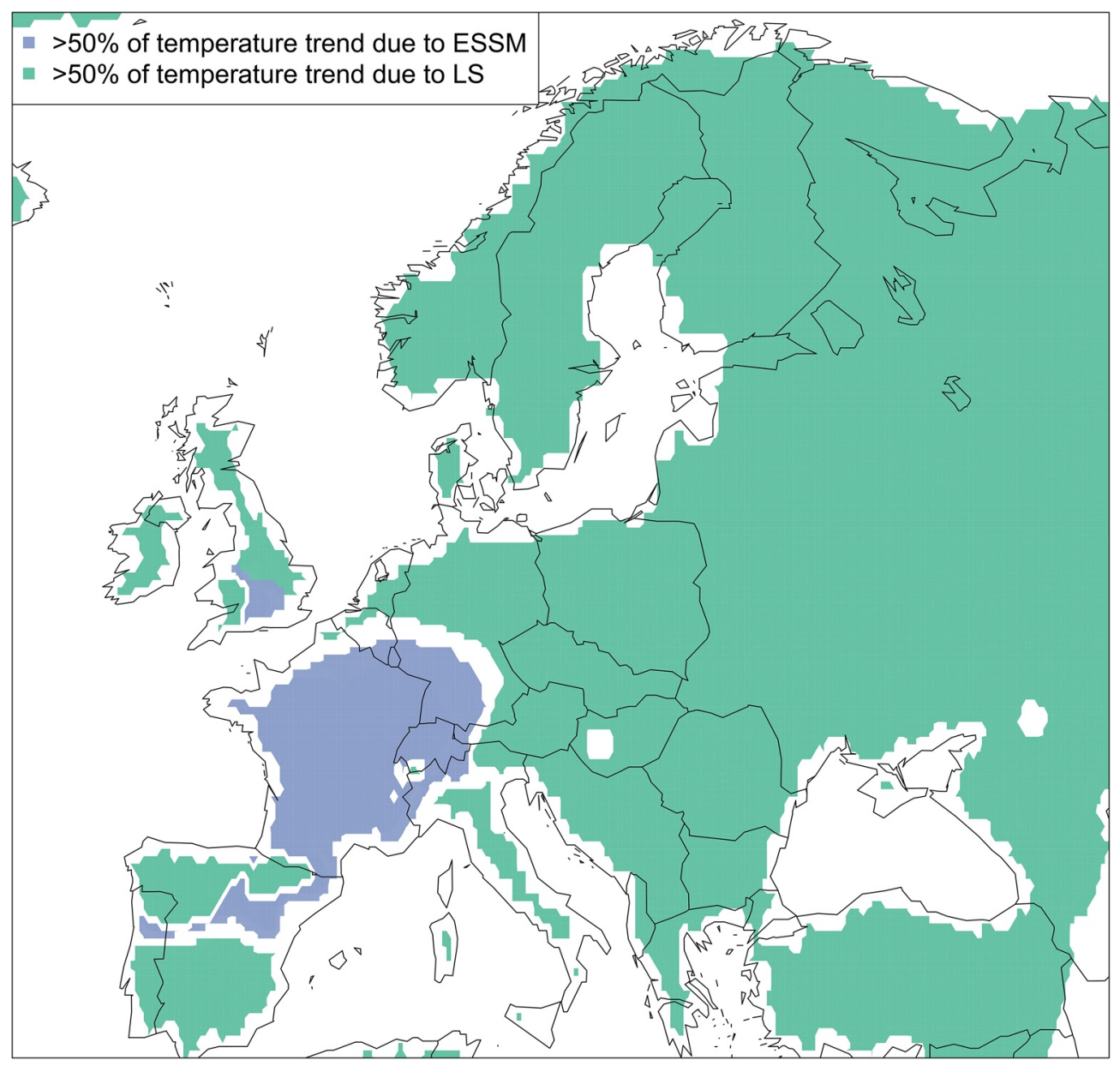

Figure 2. Areas of dominant drivers explaining the warming trend. The colors represent areas where the contribution of early summer soil moisture (ESSM) (purple) and large-scale drivers (LS) (green) explains more than $50 \%$ of the warming trend.

2010 in Russia, where it contributed $10 \%-15 \%$ to the total temperature anomaly (Figures 1d and 1e). The importance of LS was larger than that of ESSM in the heatwave years, reaching $2{ }^{\circ} \mathrm{C}-3^{\circ} \mathrm{C}$ in France and central Europe in 2003 and $5^{\circ} \mathrm{C}-6^{\circ} \mathrm{C}$ in Russia in 2010 (Figures 1c and 1f). A smaller contribution of soil moisture in contrast to atmospheric influence on heatwaves was also found in previous studies although the fractions were slightly different (Merrifield et al., 2019; Wehrli et al., 2019). The sum of the two contributions is nearly equal to the modeled anomaly itself, indicating weak or no nonlinear interactions between ESSM-driven mechanisms and LS-driven mechanisms (See correlations between the sum of the two contributions and the temperature anomaly itself in Figure S2b and S2d).

The control simulation reproduces well the 2003 and 2010 July and August mean temperature anomalies. The bias over Europe remains lower than about one degree during both summers, which had temperature anomalies up to $6^{\circ}$, giving confidence in the process analysis (Figure S5 and Stegehuis et al., 2015). A good model skill was also found for other summers (not shown). The average summer temperature bias over 1980 to 2011 was of similar magnitude except for some small regions as in the Alps, the Pyrenees and parts of the Northern Iberian Peninsula. Summer precipitation is mostly underestimated over Southern Europe, where rain is essentially absent during the summer, with largest deviations (up to 60\%) in the southern part of the Iberian Peninsula, and overestimations in Scandinavia 20\% (not shown).

The relative contribution of ESSM to the interannual variance of summer temperature, including the summers of 2003 and of 2010, only reaches a modest fraction compared to that of LS (Figures 1b and 1e). At maximum, only $20 \%$ of the interannual variance of temperature is explained by ESSM variability. This 


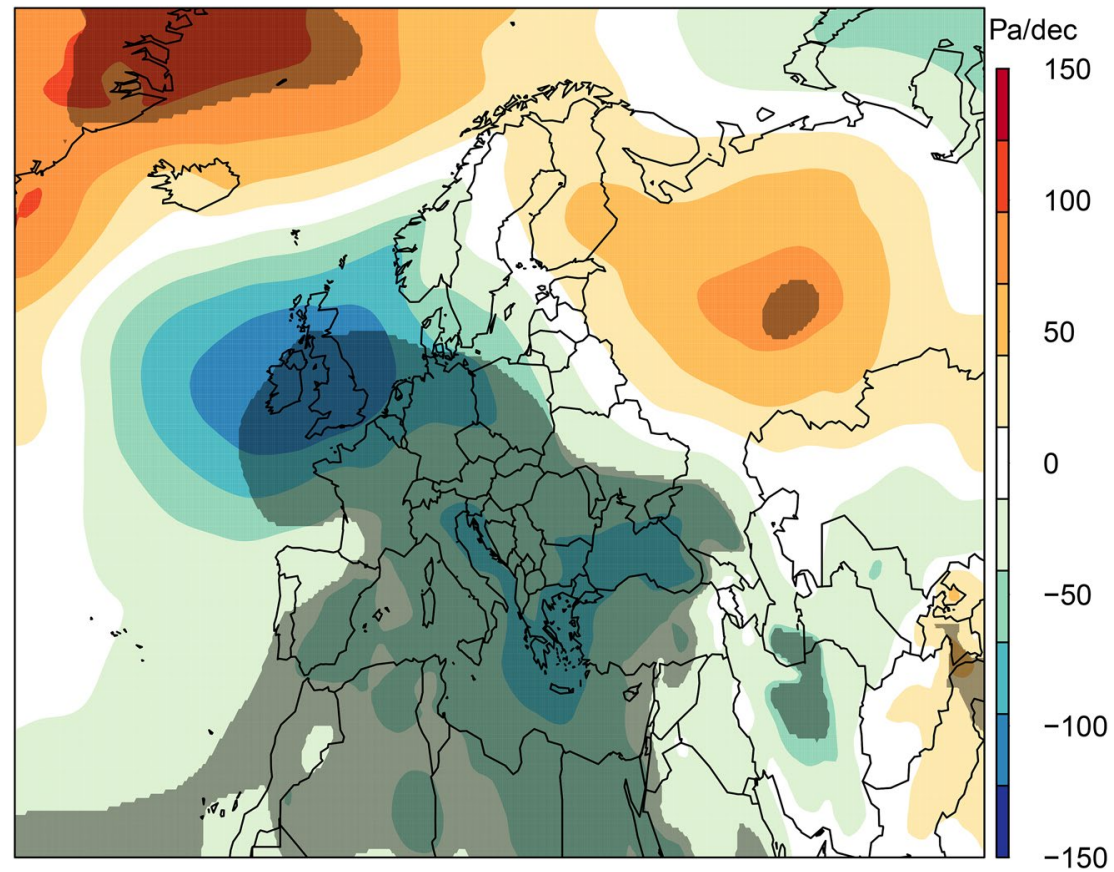

Figure 3. Trend (in Pa.decade ${ }^{-1}$ ) of sea level pressure fields over 1980-2011, using ERA-Interim reanalysis. Shaded areas indicate a significance level of $95 \%$ (MannKendall trend test) Note that the domain of the current figure is larger than the other figures to clearly show the dipole.

comes in contrast to the large contribution of ESSM trend to temperature trend outlined above. In order to assess the consistency between these two findings, we computed the interannual sensitivity of July-August temperature to ESSM. The interannual sensitivity is similar to the ratio between the temperature trend and the ESSM trends, both being of $1 \mathrm{~K}$ warming per $0.1 \mathrm{~m} 3 / \mathrm{m} 3$ change in soil moisture (see Figure 4). This

France

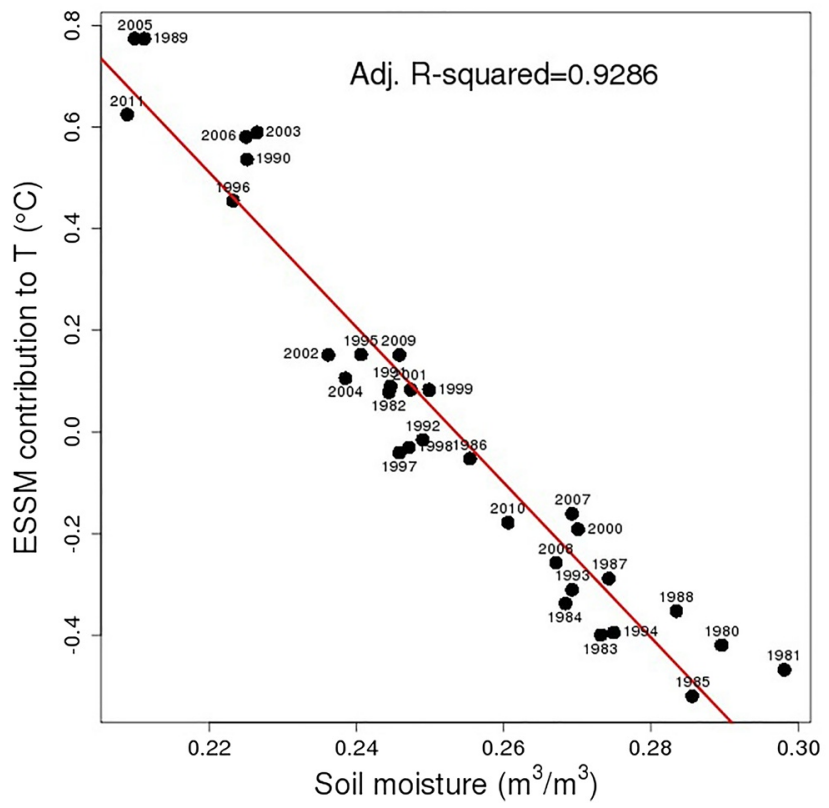

Russia

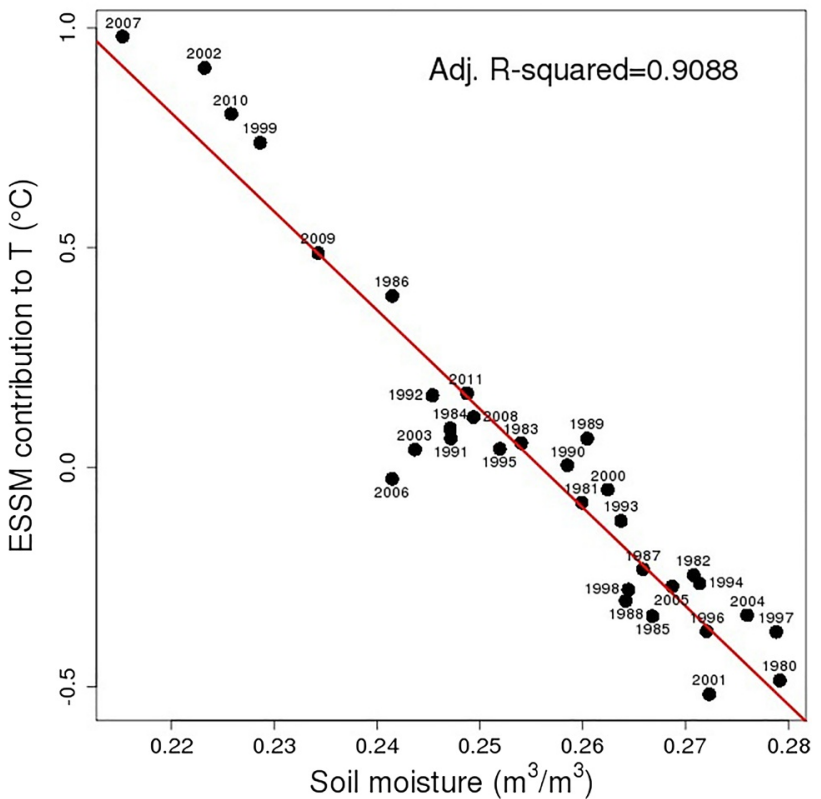

Figure 4. Relation between early summer soil moisture (ESSM) contribution to the JA temperature anomaly and ESSM, over France and Western Russia from 1980 to 2011 ( $\mathrm{p}$-value for both panels $<<0.05$; Pearson correlation test). 
confirms that similar processes, that is, a positive feedback where dry soils favor sensible heat flux over latent heat flux causing an increase in temperature that in turn depletes soil moisture, are acting at both interannual and interdecadal or long-term trend scales. Over France and Russia, the sensitivity of temperature to ESSM is large, which confirms the importance of ESSM and land-atmosphere interactions in these regions.

\section{Concluding Remarks}

In this manuscript we study the role of early summer soil moisture (ESSM) trends and that of atmospheric circulation on the long-term trends in summer warming over Europe from 1980 to 2011. We use sensitivity simulations of a regional climate model with different initial soil moisture and forced large-scale circulation. Our results reveal a key role of trends in ESSM in contributing to trends in summer climate in Western and Central Europe. This important role of ESSM is not only expected in Western Europe but could also be at play in other areas where land-atmosphere coupling is acting. Therefore, although the most recent years are not included in our analysis, the method and mechanism we reveal are still of importance for the understanding of summer climate. This result also strongly suggests for land management that favors retaining water in the soils in spring for reducing long-term summer temperature trends.

\section{Conflict of Interest}

The authors declare no conflicts of interests relevant to this study.

\section{Data Availability Statement}

ERA-Interim data was downloaded from the internet (https://apps.ecmwf.int/datasets/).

Acknowledgments

This study was supported by the Atomic Energy and Alternative Energy Commission (CEA) PhD grant of A. I. Stegehuis. It was also partly supported by the EUCLEIA (EUropean CLimate and weather Events: Interpretation and Attribution) project under the European Union's Seventh Framework Programme [FP7/2007-2013] under grant agreement no:607085." The authors would like to acknowledge ECMWF for providing ERA-Interim.

\section{References}

Barriopedro, D., Fischer, E. M., Luterbacher, J., Trigo, R. M., \& Garcia-Herrera, R. (2011). The hot summer of 2010: Redrawing the temperature record map of Europe. Science, 332, 220-224. https://doi.org/10.1126/science.1201224

Cassou, C., Terray, L., \& Phillips, A. S. (2005). Tropical Atlantic influence on European heat waves. Journal of Climate, 18(15), $2805-2811$. https://doi.org/10.1175/jcli3506.1

Ciais, P., Reichstein, M., Viovy, N., Granier, A., Ogée, J., Allard, V., et al. (2005). Europe-wide reduction in primary productivity caused by the heat and drought in 2003. Nature, 437, 529-533. https://doi.org/10.1038/nature03972

Dee, D., Uppala, S. M., Simmons, A. J., Berrisford, P., Poli, P., Kobayashi, S., et al. (2011). The ERA-Interim reanalysis: Configuration and performance of the data assimilation system. Quarterly Journal of the Royal Meteorological Society, 137, 553-597. https://doi. org/10.1002/qj.828

Denissen, J. M. C., Teuling, A. J., Reichstein, M., \& Orth, R. (2020). Critical soil moisture derived from satellite observations over Europe. Journal of Geophysical Research: Atmosphere, 125, 1-10. https://doi.org/10.1029/2019JD031672

Fouillet, A., Rey, G., Laurent, F., Pavillon, G., Bellec, S., Guihenneuc-Jouyaux, C., et al. (2006). Excess mortality related to the August 2003 heat wave in France. International Archives of Occupational and Environmental Health, 80, 16-24. https://doi.org/10.1007/ s00420-006-0089-4

Haarsma, R. J., Campos, E., Hazeleger, W., \& Severijns, C. (2008). Influence of the meridional overturning circulation on tropical Atlantic climate and variability. Journal of Climate, 21, 1403-1416. https://doi.org/10.1175/2007JCLI1930.1

Hauser, M., Orth, R., \& Seneviratne, S. I. (2016). Role of soil moisture versus recent climate change for the 2010 heat wave in western Russia. Geophysical Research Letters, 43, 2819-2826. https://doi.org/10.1002/2016GL068036

Hirsch, A. L., Evans, J. P., Di Virgilio, G., Perkins-Kirkpatrick, S. E., Argüeso, D., Pitman, A. J., et al. (2019). Amplification of Australian heatwaves via local land-atmosphere coupling. Journal of Geophysical Research: Atmosphere, 124, 13625-13647. https://doi. org/10.1029/2019/JD030665

Hirschi, M., Seneviratne, S. I., Alexandrov, V., Boberg, F., Boroneant, C., Christensen, O. B., et al. (2011). Observational evidence for soil-moisture impact on hot extremes in southeastern Europe. Nature Geoscience, 4, 17-21. https://doi.org/10.1038/ngeo1032

Hoerling, M., Eischeid, J., Perlwitz, J., Quan, X., Zhang, T., \& Pegion, P. (2012). On the increased frequency of Mediterranean drought. Journal of Climate, 25, 2146-2161. https://doi.org/10.1175/jcli-d-11-00296.1

Iacono, M. J., Delamere, J. S., Mlawer, E. J., Shephard, M. W., Clough, S. A., \& Collins, W. D. (2008). Radiative forcing by long-lived greenhouse gases: Calculations with the AER radiative transfer models. Journal of Geophysical Research Atmospheres, 113, 113-122. https:// doi.org/10.1029/2008JD009944

Jacob, D., Petersen, J., Eggert, B., Alias, A., Christensen, O. B., Bouwer, L. M., et al. (2014). EURO-CORDEX: New high-resolution climate change projections for European impact research. Regional Environmental Change, 14, 563-578. https://doi.org/10.1007/ s10113-013-0499-2

Koster, R., Mahanama, S. P. P., Yamada, T. J., Balsamo, G., Berg, A. A., Boisserie, M., et al. (2011). The second phase of the global land-atmosphere coupling experiment: Soil moisture contributions to subseasonal forecast skill. Journal of Hydrometeorology, 12, 805-822. https://doi.org/10.1175/2011JHM1365.1

Lorenz, P., \& Jacob, D. (2010). Validation of temperature trends in the ENSEMBLES regional climate model runs driven by ERA40. Climate Research, 44, 167-177. https://doi.org/10.3345/cr0097310.3354/cr00973 
Lorenz, R., Davin, E. L., Lawrence, D. M., Stöckli, R., \& Seneviratne, S. I. (2013). How important is vegetation phenology for European climate and heat waves? Journal of Climate, 26(4), 10077-10100. https://doi.org/10.1175/JCLI-D-13-00040.1

Merrifield, A. L., Simpson, I. R., McKinnon, K. A., Sippel, S., Xie, S. P., \& Deser, C. (2019). Local and non-local land surface influence in European heatwave initial condition ensembles. Geophysical Research Letters, 46, 14082-14092. https://doi.org/10.1029/2019GL083945

Miralles, D. G., Gentine, P., Seneviratne, S. I., \& Teuling, A. J. (2018). Land-atmospheric feedbacks during droughts and heatwaves: State of the science and current challenges. Annals of the New York Academy of Sciences, 1436, 1-35. https://doi.org/10.1111/nyas.13912

Miralles, D. G., Teuling, A. J., van Heerwaarden, C. C., \& Vilà-Guerau de Arellano, J. (2014). Mega-heatwave temperature due to combined soil desiccation and atmospheric heat accumulation. Nature Geoscience, 7, 345-349. https://doi.org/10.1038/NGEO2141

Morrison, H., Thompson, G., \& Tatarskii, V. (2009). Impact of cloud microphysics on the development of trailing stratiform precipitation in a simulated squall line: Comparison of one- and two-moment schemes. Monthly Weather Review, 137, 991-1007. https://doi. org/10.1175/2008MWR2556.1

Mueller, B., \& Seneviratne, S. I. (2012). Hot days induced by precipitation deficits at the global scale. Proceedings of the National Academy of Sciences, 109, 12398-12403. https://doi.org/10.1073/pnas.1204330109

Nakanishi, M., \& Niino, H. (2006). An improved Mellor-Yamada Level-3 model: Its numerical stability and application to a regional prediction of advection fog. Boundary-Layer Meteorology, 119, 397-407. https://doi.org/10.1007/s10546-005-9030-8

Omrani, H., Drobinski, P., \& Dubos, T. (2013). Optimal nudging strategies in regional climate modelling: Investigation in a Big-Brother experiment over the European and Mediterranean regions. Climate Dynamics, 41, 2451-2470. https://doi.org/10.1007/s00382-012-1615-6

Orth, R., Dutra, E., \& Pappenberger, F. (2016). Improving weather predictability by including land surface model parameter uncertainty. Monthly Weather Review, 144, 1551-1569. https://doi.org/10.1175/MWR-D-15-0283.1

Quesada, B., Vautard, R., Yiou, P., Hirschi, M., \& Seneviratne, S. I. (2012). Asymmetric European summer heat predictability from wet and dry southern winters and springs. Nature Climate Change, 2, 736-741. https://doi.org/10.1038/nclimate1536

Rasmijn, L. M., van der Schrier, G., Bintanja, R., Barkmeijer, J., Sterl, A., \& Hazeleger, W. (2018). Future equivalent of 2010 Russian heatwave intensified by weakening soil moisture constraints. Nature Climate Change, 8, 381-385. https://doi.org/10.1038/s41558-01800114-0

Samaniego, L., Thober, S., Kumar, R., Wanders, N., Rakovec, O., Pan, M., et al. (2018). Anthropogenic warming exacerbates European soil moisture droughts. Nature Climate Change, 8, 421-426. https://doi.org/10.1038/s41558-018-0138-5

Schaer, C., Vidale, P. L., Lüthi, D., Frei, C., Häberli, C., Liniger, M. A., \& Appenzeller, C. (2004). The role of increasing temperature variability in European summer heatwaves. Nature, 427, 332-336. https://doi.org/10.1038/nature02300

Seneviratne, S. I., Corti, T., Davin, E. L., Hirschi, M., Jaeger, E. B., Lehner, I., et al. (2010). Investigating soil moisture-climate interactions in a changing climate: A review. Earth-Science Reviews, 99, 125-161. https://doi.org/10.1016/j.earscirev.2010.02.004

Seneviratne, S. I., Lüthi, D., Litschi, M., \& Schär, C. (2006). Land-atmosphere coupling and climate change in Europe. Nature, 443, 205-209. https://doi.org/10.1038/nature05095

Skamarock, W. C., Klemp, J. B., Dudhia, J., Gill, D. O., Barker, D. M., Wang, W., et al. (2008). A description of the advanced research WRF Version 3. National Center for Atmospheric Research. https://doi.org/10.5065/D6DZ069T

Stefanon, M., Drobinski, P., D'Andrea, F., Lebeaupin-Brossier, C., \& Bastin, S. (2014). Soil moisture-temperature feedbacks at meso-scale during summer heat waves over Western Europe. Climate Dynamics, 42, 1309-1324. https://doi.org/10.1007/s00382-013-1794-9

Stegehuis, A. I., Vautard, R., Ciais, P., Teuling, A. J., Miralles, D. G., \& Wild, M. (2015). An observation-constrained multi-physics WRF ensemble for simulating European mega heat waves. Geoscientific Model Development, 8, 2285-2298. https://doi.org/10.5194/ gmd-8-2285-2015

Teuling, A. J. (2018). A hot future for European droughts. Nature Climate Change, 8, 364-365. https://doi.org/10.1038/s41558-018-0154-5

Tewari, M., Chen, F., Wang, W., Dudhia, J., Lemone, M. A., Mitchell, K. A., et al. (2004). $20^{\text {th }}$ conference on weather analysis and forecasting/16 th conference on numerical weather prediction (pp. 11-15). Implementation and verification of the unified Noah land surface model in the WRF model.

Tiedtke, M. (1989). A comprehensive mass flux scheme for cumulus parameterization in large-scale models. https://doi. org/10.1175/1520-0493(1989)117

Van Hateren, T. C., Chini, M., Matgen, P., \& Teuling, A. J. (2021). Ambiguous agricultural drought: Characterising soil moisture and vegetation droughts in Europe from earth observation. Remote Sensing, 13. https://doi.org/10.3390/rs13101990

Van Oldenborgh, G. J., Drijfhout, S., van Ulden, A., Haarsma, R., Sterl, A., Severijns, C., et al. (2009). Western Europe is warming much faster than expected. Climate of the Past, 5, 1-12. https://doi.org/10.5194/cp-5-1-2009

Vautard, R., Yiou, P., D'Andrea, F., de Noblet, N., Viovy, N., Cassou, C., et al. (2007). Summertime European heat and drought waves induced by wintertime Mediterranean rainfall deficit. Geophysical Research Letters, 34, 1-5. https://doi.org/10.1029/2006GL028001

Wehrli, K., Guillod, B. P., Hauser, M., Leclair, M., \& Seneviratne, S. I. (2019). Identifying key driving processes of major recent heat waves. Journal of Geophysical Research: Atmosphere, 124, 11746-11765. https://doi.org/10.1029/2019JD030635

Wild, M., Gilgen, H., Roesch, A., Ohmura, A., Long, C. N., Dutton, E. G., et al. (2005). From dimming to brightening: Decadal changes in solar radiation at earth's surface. Science, 308, 847-850. https://doi.org/10.1126/science.1103215

Zampieri, M., D'Andrea, F., Vautard, R., Ciais, P., de Noblet-Ducoudré, N., \& Yiou, P. (2009). Hot European summers and the role of soil moisture in the propagation of Mediterranean drought. Journal of Climate, 22, 4747-4758. https://doi.org/10.1175/2009JCLI2568.1

Zampieri, M., Russo, S., di Sabatino, S., Michetti, M., Scoccimarro, E., \& Gualdi, S. (2016). Global assessment of heat wave magnitudes from 1901 to 2010 and implications for the river discharge of the Alps. The Science of the Total Environment, 571, 1330-1339. https:// doi.org/10.1016/j.scitotenv.2016.07.008

Zhang, C., Wang, Y., \& Hamilton, K. (2011). Improved representation of boundary layer clouds over the southeast pacific in ARW-WRF using a modified Tiedtke cumulus parameterization scheme. Monthly Weather Review, 139, 3489-3513. https://doi.org/10.1175/ MWR-D-10-05091.1 